\title{
Al-Biruni: A Muslim Critical Thinker
}

\author{
Mohammad Noviani Ardi ${ }^{*}$ \\ Fatimah binti Abdullah² \\ Shihab al-Tamimi ${ }^{3}$ \\ 1'International Islamic University Malaysia.
2Department of Ushuluddin and Comparative Religion, Islamic Revealed Knowledge and Human
Science, International Islamic University Malaysia. \\ 3/slamic Revealed Knowledge and Heritage in Ushuluddin and Comparative Religion, International \\ Islamic University Malaysia.
}

${ }^{*}$ Corresponding Author, Email: ardie.iium@gmail.com

\begin{abstract}
:
As an academic course, critical thinking has emerged in the last century as the one of the important subjects, especially in the second half. But as a kind of thinking and a process of the human reason, it was existed as old as mankind. What are known, nowadays, as (standards) of critical thinking or (characteristic) of critical thinker were used by some ancient Greek philosophers, e.g. Socrates, Aristotle, as well as great Muslim scholars, e.g. al-Biruni, al-Ghazali, etc. al-Biruni was known as a great Muslim scholar due to objectively scientific method in his works. Moreover, he also was famed in comparative religion which early in history of discipline of comparative religion. However, this study attempts to talk about al-Biruni, one of greatest Muslim scholar in history from another side of previously discussion. It is tries to analyze al-Biruni as a Muslim critical thinker based on his monumental work of Tahqīq mā li al-Hind min Ma'qūlah Maqbūlah fĩ al-'Aql aw Mardhūlah or it is known by Kitāb al-Hind.
\end{abstract}

Keywords: Al-Biruni, Critical Thinker, Muslim

\section{A. INTRODUCTION}

Al-Biruni was really a great Muslim scholar and as a famed of Central Asia, Pakistan, and India (Ibrahim, 1976: iii). He became the founder of Muslim thinker after him in the several field of science and especially in the comparative religion. He provided necessary methods and precise guidelines for future scholars who wish to embark on similar studies. His works clearly show that he was developing a methodology for scientific study of religions. In June 1974, the UNESCO Courier magazine specified the issue of June on al-Biruni under the topic (A Universal Genius in Central Asia a Thousand Years), and described him as astronomer, historian, botanist, pharmacologist, geologist, poet, philosopher, mathematician, geographer, and humanist (The UNESCO Courier, 1974: 1).

Moreover, many western scholars also impressed to al-Biruni. They translated several al-Biruni's works to their languages. In the 1866 Russian orientalist Nicholas de Khanekoff first drew attention 
of the European scholars towards the scholarly work of al-Biruni (Riaz, 2009: 10). Although Edward Sachau, the German scholar, translated two important works of al-Biruni, the al-Athar and the Kitāb al-Hind in 1878 and 1887 respectively. In addition, al-Tafhïm book has been translated by Wright with the title "The book of Instruction in the Element of the Art of Astrology", and alSaydaliyya book also has been translated by Muhammad Said with the tittle "al-Biruni's Book on Pharmacy and Materia Medica" (Othman, 2009: 173).

Based on the short brief of the academic background of al-Biruni, we can see that he was the greatest Muslim thinker and scholar that Islam had in the thousand years ago. He had interdisciplinary as well as open minded when he was striving to study, to observe, to analyze, and to construct the new method or formula about science and other field of knowledge.

\section{Al-Biruni's Background Life and His Academic Journey}

Abu al-Rayhan Muhammad ibn Ahmad al-Biruni was born in $2^{\text {nd }}$ of Dzū al-Hijjah 362 A.H., which is equivalent to $4^{\text {th }}$ of September 973 A.C. (Al-Shahb, 1968: 7). However, the place of al-Biruni's birth has indicated differences, some scholar said that al-Biruni was born in a town called Birun, which was in Sind, but it has no authentic historical record has been found to identity it on the maps of ancient Sind. ${ }^{1}$ On other hand, Soviets scholars delving deep into the entrails of bygone centuries, have come out with the conclusion that al-Biruni was born at Khiva in Uzbekistan. There is yet another authority who maintains that he was born in Khawarizm in Central Asia (G. Allana, 1979: 150), hence al-Biruni is sometimes called simply al-Khawarizmi. But, whatever be the place of his birth, it would be historically correct to say that he did not languish in poverty while he lived.

He died on the Rajab 440 corresponding to $13^{\text {th }}$ of December 1048 (Kamaruzzaman, 2003: 29), but according to some scholars, he supposed to be alive until (442/1050) because in this year he wrote his book al-Șaydaliyya fĩ al-Ṭibb (Muntashir, 1968: 19).

When al-Biruni was born in $973 \mathrm{M}$, Persian civilization was in full efflorescence. In the same year 973, Cairo was definitively founded as capital of the Fatimids (Spuler, 1979: 289). The unique social culture and strong attachments to national tradition, among other things, contributed to the on-going development of the Persian countries. Spuler also notes that the strong agrarian base of the country ensured its economic stability despite the wars at that time.

Indeed, these Eastern Region of the Muslim Empire during the age of al-Biruni was not only politically powerful, but also highly cultured, literature, arts, and the science were significantly developed and found support among the ruling houses (Kamaruzzaman, 2003: 35). The academic treasure forms the Muslim scholarship in the era of Abbasid Caliphs were available, then followed by caliphs and dynasty after them became greatest treasure according to al-Biruni books, original, and translation, were easily available and the new technology of book production learnt from Chinese great helped in the spread of knowledge (Kamaruzzaman, 2003: 43). Consequently, a consideration of this evolution may be important for the understanding of al-Biruni's career.

However, as for al-Biruni's childhood and early education, not much is known about them. Scholar believe that he went through the normal school system of the time, the maktab (elementary school) and madrasah (a religious school), and learned the regular Islamic subjects such as tafsir (exegesis), ahāāith (prophetic tradition), Arabic language and grammar, figh (Islamic

\footnotetext{
1 Al-Bladhri illustrates that the Muslim leader Muhammad ibn al-Qasim (62-98/681-717) captured Birun during this moving to conquest (Sind), which means that it was a famous city in that time. See, Ahmad Ibn Yahya Al-Baladhiri, Futuh al-Buldan, (Bayrut: Dar wa Maktabat al-Hilal, 1988), 421.
} 
jurisprudence), history, etc. There is no mention of his teachers in his extant works, with the exception of a reference to Abu Nasr Mansur, the Iraqi princes, as ustādh (teacher) (Kamaruzzaman, 2003: 44), as well as Abu Sahl al-Taflisi (al-Biruni, 1983: 14). al-Biruni spent his live in two empires both Samaniyyah and Ghzanawiyyah. Although at the time the political situation was not suitable, but the development of knowledge still continuously high progress.

Al-Biruni childhood was spent in Birun, but he had to leave at the age of twenty-three due to political problem. He went to Rayy, a famous center for astronomy during that time, and by difficulties in Rayy, but nevertheless was there for about three years and benefitted much from their observatory. There, he evolved a trigonometrically method for measuring the earth (Kamaruzzaman, 2003: 31).

After three years in Rayy he went to Jurjan at the invitation of its ruler, Sultan Shams al-Ma'ali bin Qabus. There he completed, in 390/999, his famous book Kitab al-Athār and dedicated it to the Sultan. Then al-Biruni dedicated also another book, Risālat al-Tajrīd al-Sha'at, to the same Sultan. In Jurjan, al-Biruni started his preliminary works on measurement of the earth's latitude (Kamaruzzaman, 2003: 31; at-Thaba', 1993: 27).

After ten years in Jurjan, upon receiving an invitation from the new Ma'munid ruler Abu al-Hasan 'Ali (400/1009-1010), al-Biruni left for Khawarizm. Khawarizm at the time was bloomed and prospered, in particularly in the field of scholarship under the government of Abu al-Hasan and later his brother Abu al-Abbas.

Furthermore, al-Biruni was taken a prisoner to Ghaznah by Sultan Mahmud of Ghazna (d.422/1030) when the later brought Khawarizm under his control. In Ghzanah, al-Biruni genius and academy maturity came to full bloom. Mahmud died in the year 422/1030, and the later Mas'ud became the leader of Ghaznah in 422/1031. Mas'ud esteemed for scholarship and scholar was at least equally great, it's differently condition when Abu al-Hasan was a ruler. Towards, alBiruni was especially appreciative and supportive to him and he dedicated with Qanūn al-Mas'ūdī. Mas'ud was killed in military expedition. His son, Mawdud, avenged his death and became next Sultan. He was kind to al-Biruni dedicated his book Kitāb al-Dustūr to Sultan Mawdud who ruler until 441/1049 and the last Sultan al-Biruni served.

Al-Biruni was so far ahead for his time that his most brilliant discoveries seemed incomprehensible to most of the scholar of his day. He was the first to arrive at an amazingly simple formula for measuring the earth's circumstance. He thought it possible that the earth revolved around the sun. $\mathrm{He}$ developed the idea that geological eras succeed one another in cycles. He had a brilliant hypothesis based his theory that "with the passing of time", the sea becomes dry land and dry land the sea" (Gavurof, 1974: 5).

In addition, to personal contact with numerous Muslim, Christian and Hindu, scholar and sages of his time, al-Biruni also had access to many ancient works of Greek, Babylonia, and Zoroastrian science (Nowshervi, 1979: 582).

\section{B. METHODS}

This study uses content analysis in one of his monumental book of al-Hind as a main source and other literatures compare with standard of categorization of critical thinking and characterization of critical thinker. The ruler supported the scholarship development among them and al-Biruni expert on it. It was benefit role according to al-Biruni in gaining and development his research, such as 
the studies of the Indian's culture and religion that al-Biruni around fourteen years was there to do research.

\section{RESULT AND DISCUSSIONS}

\section{1. al-Biruni as a Muslim Critical Thinker Based on His Works}

It seems that one of precise definitions of critical thinking is Jay Verlinden's. Verlinden says, "Critical thinking is the active application of principles of reasoning to your own ideas and those of others to make judgment about communications and reasoning, to analyze arguments, to expose underlying assumptions, to achieve understanding, and to approach the truth" (Verlinden, 2005: 19). In addition, Reichenbach illustrates six particular steps for critical thinking, which are: knowledge, comprehension, application, synthesis and evaluation (Reichenbach, 2001: 20-26). On other hand, Bassham, Irwin, Nardone, and Wallace realize eight standards of critical thinking, which are (Bassham, Irwin, Nardone, \& Wallace, 2012: 2-6):
a. Clarity
b. Precision
c. Accuracy
d. Relevance
e. Consistency
f. Logical correctness
g. Completeness, and
h. Fairness

Moreover, the characteristic of critical thinkers, according to Ruggiero, are (Ruggiero, 2002: 47$52)$ :

a. They are honest with themselves

b. They resist manipulation

c. They overcome confusion

d. They ask question

e. They take the time to produce many ideas

f. They base their judgment on evidence

g. They acknowledge complexity

h. They look for connection between subjects

i. They are intellectually independent

All these boundaries, standards, characteristic of critical thinking and critical thinker, we can find them obviously applied on our figure, al-Biruni, in his works and his knowledge trip.

Al-Biruni became the asserter or affirmer for several sciences on this earth neither Muslim scholar nor Western scholar in modern science development. Surely, this kind of gaining of knowledge not only by reading hundred books but also need to tafakkur (contemplating), tadhakkur (taking of heart), tadabbur (pondering), tafaqquh (comprehending), tabașșur (understanding), tawassum (reflecting), nadhar (considering), and i'tibār (raking a lesson) as well as Jamal Badi said in his book (Badi \& Tajdin, 2004: 3-7). Unfortunately, in the modern era, the most of western scholar applied it than most Muslim scholar to their next observation and they claimed their works. 
In the Muslim East, the tenth century was a time of brilliant intellectual progress. al-Biruni was a one of great Muslim scholar; he had various academic trips to several countries that it has great role according to his academic progress maturely. When he died at the age of 78 years old, he left a vast treasure of knowledge in various field of scholarship. These include about 114 books and journals, in which 18 were on astronomy, 15 on geography, 4 on light rays and sight, 5 on tailed stars, 7 on astrology, 14 on light reading, and humor, 6 on religious beliefs, and 22 books on miscellaneous subject including astronomy, geography, universal, phenomena, travel, etc. (Aziz, 1979: 158). Some noteworthy contributions of al-Biruni's researches were held including on (Aziz, 1979: 159; al-Thaba', 1993: 48):

a. Trisection of an angle, and solution of some complex problem without the use of protractors and scale.

b. Accurate determination of latitude and longitude of a large number of places.

c. Pointing to the existence of the American continent.

d. Putting forward his theory that the Sind valley was under at some time in the past, which later changed into dry land following some geographic changes.

e. Explaining the flow of spring on the principle that water finds its own level.

f. Determination of specific gravity of 18 precious stones and metals.

g. Providing proof that light travels at a much faster speed than sound.

h. Explaining the forces of gravity.

i. Throwing light on gravitation force.

j. Devising methods to identity a number of precious stones.

$\mathrm{k}$. Explaining the phenomenon of five visible at the of sun eclipses.

I. Providing useful information and views about the height of various trees.

$m$. Discussion on the issues whether the earth revolves round its axis or not.

$\mathrm{n}$. Explaining on the universal law of nature that flowers have always $3,4,5$, 6 , or 8 petals, and never 7 or 9 .

o. Determination of the circumference and diameter of the earth by using spherical trigonometry.

p. Determination of sun's declination and zenithal movement.

Al-Biruni was famous among scholarship that he had well accuracy research. Moreover, the scientific method advocates direct study of facts accurately and objectively. al-Biruni did that, especially in his Kitāb al-Hind, he displayed a true scientific study, to provide a reliable and authentic guidance for those who wanted to take up polemics with the Hindus. In his effort, mere hearsay was discarded, and so also in second hand information and only concrete and personally observed practice in all fields of Hindo society were recorded. Whenever, the records are insufficient does not hazard a guess but informs the reader frankly of his limitation (Warris, 1979: 277).

In addition, al-Biruni was objectively researcher as far as al-Biruni's method of communication is concerned, he himself enlightens us:

In most parts of my work I simply without criticizing, unless there be a special reason for doing. So, I mention the necessary Sanskrit names and technical terms once where the context of our explanation demands it. If the word is an original one, the meaning of which can be rendered in Arabic. I only use the corresponding Arabic word; if, however, the Sanskrit word be more practical word, we keep this, trying to transliterate it as accurately as possible. If the word is a secondary or derived one, but in general use, we also keep it, though there be a corresponding 
term in Arabic, but before using it we explain its signification. In this way we have tried to facilitate the understanding of the terminology" (Dani, 1979: 182).

On the other hand, in al-Biruni's al-Qanūn al-Mas'ūdī, a number of problem of mathematical geography have been discussed. Another of his books, Kitāb al-Tafhīm deals with Cosmography, astronomical, and geographical topics (Israuddin, 1979: 206).

Al-Biruni seems that he was concern science deeply relevant to need in that era. Moreover, he brought new orientation to those contributions, corrected many of the errors in the past works and acknowledged the contributions where due, like a true scientist as well as western scientist.

Al-Biruni believed in the sphericity of the Earth and also discussed the antipodes. To some European scholars of his period their ideas were abhorrent and incredible and they were unable to believe that human life could be possible at the antipodes. al-Biruni also fully understood the phenomena that the polar areas enjoy 24 hours days in summers and continuous right in winters. He fully grasped the obliquity of ecliptics. With regard to earth movement, he rightly viewed its rotation on its own axis, but believed that the sun revolves round the earth (Israuddin, 1979: 206).

In cartography, al-Biruni fully appreciated the problem involved in transferring the map of three dimensional and spherical Earth, and flat two-dimensional papers. Thus, he invented stereographic projections. In his Kitāb Tafhìm be prepared a round map of the world to illustrate the position of the seas, and in another book Athār al-Baqiyyah he devised a method of projection of maps of the sky and the earth. He has also drawn many maps of various countries of the known world (Israuddin, 1979: 207).

Surprisingly, al-Biruni was one of the greatest astronomers of Islam. He wrote two books on astronomy. Kitāb al-Tafhīm fĩ Șinā'ah al-Tanjīm (Exploitation of the science of Astronomy) was written in A.D. 1029 at Ghaznah and was dedicated to Rehanah, daughter of Husayn Khawarizm. Originally, it was in Arabic, but the author later translated it into Persian. It may be regarded as a primer of $11^{\text {th }}$ Century science. Apart from discussions on geometry and astronomy and the use of the astrolabe, it treats geography and chronology also (Nasim, 1979: 580).

The work of al-Biruni was known interdisciplinary, that can be considered as sociological is in his study if India. His Kitāb Taḥqĩ mā li al-Hind (The Book of What Constitutes India) aimed to provide a comprehensive account of what he called "the religion of India and their doctrines". This included the religion, philosophy, literature, geography, science, custom, and law of the Indians. We should stop here with this book to know close up al-Biruni methodology and to consider the Islamic critical thinking of him.

\section{2. al-Biruni, a Critical Thinker Through his India}

The original name of this book in Arabic is Tahquīq mā li al-Hind min Ma'qūlah Maqbūlah fĩ al-'Aql aw Mardhūlah, and it was translated into English by Edward C. Sachau under the name al-Biruni's India. al-Biruni traveled to India and lived in the Hindu society in order to know as much as possible about Hindus, their social system, life style, science, tradition, and religion. In following, there are some noteworthy points about al-Biruni thought and methodology. 


\section{a. Specialist in Various and Diverse Science}

As mentioned above, al-Biruni is scolar in different domains of knowledge and a scientist in diverse fields. That is obvious enough in his book Tahquīq mā li al-Hind. He does not discuss Hinduism as a religion and tradition only, but he discusses, furthermore, Hindu's history, philosophy, and literature. He also exams, Hindu's sciences in metrology, mathematics, geography, cosmography, chronology, and astronomy. It could be said frankly that no scholar could do such work if he does not have deep knowledge in all mentioned disciplines.

\section{b. Good observer is good thinker}

In this book, al-Biruni criticizes authors who just depend on information which is transferred from others with using their own observations, or receive reports from others without analyzing and critiquing them (al-Biruni, 1983: 13; Sachau, 1910: 1/3). He urges to use good observation and sound reason to study any circumstance. To study Hindu religion, tradition, sciences, and society, the traveled to India, lived with Hindus, read their books and asked their scholars and monks. Hence, it is found that the first sentences in his book is "No one will deny that in question of historic authenticity hearsay does not equal eye-witness". al-Biruni is intellectually independent, depends on his own observation and analyzes the information which is got from others.

\section{c. Language is a key element}

Language in the container of information. Therefore, it is so important for the critical thinker. He needs a clear and precise language for communication; receiving and bequeathing the information. In this regard, al-Biruni, who masters several languages, had persisted to get Sanskrit in order to understand Hindu religion, and sciences profoundly. He translated several Greek books to his language for Hindus as well as translating some particular Hindus books to Arabic (al-Biruni, 1983: 16, 96, 110; Sachau, 1910: 1/8, 137)2. Moreover, he does a comparison between Syria, Hebrew, and Arabic languages in some words and reveals that there are some similarities and differences (al-Biruni, 1983, 30).

\section{d. Asking question is a means of precise comprehension}

Al-Biruni always asks question then seeks for the answers. Sometimes, he gets the answer from his reading or observing, but sometimes he needs to ask people who concern or relevant for instance, he says in his book: "I have repeatedly been told that when Hindu slaves (in Muslim countries) escape and return to their country and religion, the Hindus order that they should fast by way of expiation, then they bury them in the dung, stale, and milk of cows for a certain number of days, I have asked the Brahmans if this is true, but they deny it, and maintain that there is no expiation possible for such an individual" (al-Biruni, 1983: 434; Sachau, 1910: 2/163.

\section{e. Judgment and conclusion based on evidence}

As he persists to get authentic sources for his information, al-Biruni persist to get enough evidences before reaching the conclusions. Hence, while the vast majority of Muslim scholars describe Hindu as idolaters, al-Biruni asserts that common people of Hindu seem idolaters but

2 For instance, he translated Euclid and of the Almagest, in the construction of the astrolabe, into Sanskrit. He also translated Sdmkhya, about the origines and a description of all created beings, and Patanjali, about the emancipation of the soul from the fetters of the body. (al-Biruni, 1983: 16, 96). 
educated people or scholars among them are theist. Then, he provides evidence from their books, he says about educated Hindus that they "believe with regard to God that he is one, eternal, without beginning, and end, acting by freewill, almighty, all wise, living, giving life, ruling, preserving, one who in his sovereignty is unique, beyond all likeness and unlikeness" (Sachau, 1910: 1/27). Then he says, "in order to illustrate this we shall produce some extract from their literature, least the reader should think that our account is nothing but hearsay. In the book of Patanjali ...", and quotes from some Hindu books.

\section{f. Look of connection between subjects}

Al-Biruni does not stop when he gets single information about subject or issue. He tries to attain information as much as he can to get good comprehension about the subject. He insists to look for the connection between subjects. As an example, al-Biruni mentions in his India the names and meanings on the Puranas, a series of Hindu books in history and jurisprudence. He has two sources in this regard, so he illustrates both. He says, "In the following I give a list of their names, as I have heard them, and committed them to writing from dictation ...." (al-Biruni, 1983: 91; Sachau, 1910: 1/130). Then he points out them from the second source, "another somewhat different list of the Purana has been read to me from the Vishnu-Purana. I give it here in extenso, as in all questions resting on tradition it is the duty of an author to give those traditions as completely as possible ...", and after that he makes a comparison.

Moreover, al-Biruni compares between different Hindus' opinions in one issue and tries to find the connections between them, he does such in issues as the order of the planets and their distance (al-Biruni, 1983: 360; Sachau, 1910: 2/60), the details of Brahmins' life and what they are obliged to do during their whole life (al-Biruni, 1983: 412; Sachau, 1910:2/130), and which social castes is capable of attaining to liberation, al-khalash (al-Biruni, 1983: 73; Sachau, 1910: 1/104).

\section{g. Dealing with other in fairness}

This is obvious enough in al-Biruni's Tahqīq mā li al-Hind. He does not judge others according to their background, or deny their good deeds and epistemological contributions because of their religions. In fact, that is not mere al-Biruni's approach, it is a divine order when Allah says:

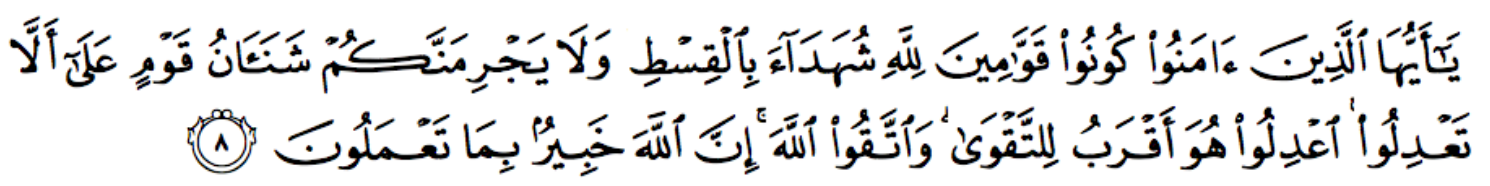

O ye who believe! Stand out firmly for Allah, as witnesses to fair dealing, and let not the hatred of others to you make you swerve to wrong and depart from justice. Be just: that is next to Piety: and fear Allah. For Allah is well acquainted with all that ye do (QS. Al-Maidah: 8).

Al-Biruni does not generalize in any issue unless he is sure. Therefore, he tries to find out all opinions about an issue (al-Biruni, 1983: 36, 412). Furthermore, he asserts many times that Hindu people are groups, educated people and uneducated people, and there are differences between them in beliefs and life style (al-Biruni, 1983: 23, 25, 31, 47, 78, 79, 426). In arguments, moreover, al-Biruni indicates good attributes and characteristics of people who are in opposite side. For example, he says when he was discussing an idea of Indian philosopher: "I, for my part, am inclined to the belief that which made Brahmagupta speak the above-mentioned words (which involve a sin against conscience) was something of a calamitous fate, like that of Socrates, which 
had befallen him, notwithstanding the abundance of his knowledge of his knowledge and the sharpness of his intellect, and notwithstanding his extreme youth at the time" (al-Biruni, 1983: 396; Sachau, 1910: 2/60).

\section{h. Logic arguments}

The reader of al-Biruni's India never feel bored, he goes alongside with al-Biruni chapter by chapter especially when al-Biruni goes in argument and moves logically step by step. Logic arguments in this book are found more in subject like metrology, geography, astronomy, and astrology. For example, in $51^{\text {st }}$ chapter, he argues the wrong statements of Ya'qub ibn Thariq, a Muslim scholar, in metrology and reveals his mistakes (al-Biruni, 1983: 328). Also he argues, in $59^{\text {th }}$ chapter, that the eclipse of sun occurs naturally when the moon cover the sun not as Hindu myths (al-Biruni, 1983: 394).

\section{i. Honest with himself}

The critical thinker in honest with himself (Ruggiero, 2002: 47), which means that he admits his limits. He known that knowledge, in most cases, is assortment of facts, assumptions, and conclusion. So he is cautious about claiming certainty or pretending that the truth is in his side. As an honest thinker, al-Biruni deals honestly with several subjects in Tahqqīq mā li al-Hind. For instance, in the beginning of $8^{\text {th }}$ chapter which is about the different classes of created beings in Hindu belief, he asserts: "The subject of this chapter is very difficult to study and understand accurately, since we Muslims look at it from without, and the Hindus themselves do not work it out to scientific perfection. As we, however, want it for the further progress of this treatise, we shall communicate all we have heard of it until the date of the present book" (al-Biruni, 1983: 63; Sachau, 1910: 1/89). In addition, al-Biruni indicates several times that he cannot claim any details about some Hindu doctrines because no authentic sources about them he can relies (al-Biruni, 1983: 134, 178, 232, 236), also he asserts that his sources of information about Buddhism is not authentic (al-Biruni, 1983: 183).

Moreover al-Biruni sometimes indicates that he has not fully certainty about the result of his analyzing and deducing. Hence, there are many phrases in his book like, "I think", "it is likely that", "I am not sure", and so on.

\section{j. Integrating between the reason and the revelation (al-'Aql and al-NaqI)}

Muslim critical thinker does not depend only on his reason because he believes that there are facts which are beyond the power of human reason and the capacity of the brain in bounded. Hence, he depends, with the sound reason, on divine revelation which never ever be mistaken. alBiruni, as a Muslim critical thinker, integrates in his studies between 'Aql and Naql. He does such, for example, when discusses the Hindu doctrine about the solar and lunar eclipses (al-Biruni, 1983: 393).

\section{CONCLUSION}

In strict sense, Abu al-Rayhan al-Biruni is a great Muslim critical thinker. His thinking was based upon his bounteous knowledge as well as his religious personality and education. He uses clear language and logic method in his arguments. He integrates between the reason and the revelation (al-'Aql and an-Naql). Moreover, he has serious contributions in diverse fields of science and branches of knowledge with fully succeeding in reflecting of standard of critical thinker such as 
fairness with objective method in his observation, logical correctness in receiving information with precision analyses, and he always come to his conclusion with clear evidences. Furthermore, one of another important point as the fundamental basic of a critical thinker is honesty in his observations. Considering the facts of characteristic of al-Biruni in his works especially in his book of al-Hind in dealing with Indian society, it is fair to say Abu Rayhan al-Biruni deserve recognition as a great Muslim Critical Thinker. In fact, writing about al-Biruni as a critical thinker is not an easy task to do. It is a topic which may occupy a dissertation or a book. Hence, it is recommended to be a topic for a precise and comprehensive study. 


\section{References}

Al-Baladhiri, Ahmad Ibn Yahya. (1988). Futūḥ al-Buldān. Bayrut: Dar wa Maktabat al-Hilal.

al-Biruni, Muhammad ibn Ahmad. (1983). Taḥqīq mā li al-Hind min Ma'qūlah Maqbūlah fĩ al-'Aql aw Mardhūlah. Bayrut: 'Alam al-Kutub.

Al-Shahb, Ali Ahmad. (1968). Abū al-Rayhān al-Biruni. Misr: Dar al-Ma'arif.

al-Thaba', 'Umar Faruq. (1993). Abū al-Rayḥān al-Birūnī. Bayrut: Mu'assasat al-Ma'arif.

Allana, G. (1979). Abū al-Rayḥān Muḥammad Ibn al-Birūnī, in Al-Biruni Commemorative Volume. Karachi: The Times Press.

Aziz, Ghulam Rabbani. (1979). Al-Biruni and his Academic Conquests, in al-Biruni Commemorative Volume. Karachi: The Times Press.

Badi, Jamal \& Tajdin, Mustapha. (2004). Creative Thinking: An Islamic Perspective. Malaysia: Research Center IIUM.

Bassham, Irwin, Nardone, and Wallace. (2012). Critical Thinking a Student's Introduction. USA: Library of Congress, 2012.

Dani, Ahmad Hasan. (1979). Al-Biruni's India a re-evaluation, in al-Biruni Commemorative Volume. Karachi: The Times Press.

Gafurov, Bobojan. (1974). Abu al-Rayhan Mohammed ibn al-Biruni. Paris: Unesco.

Ibrahim, Muhammad Kalab. (1976). Biruni Symposium Colombia: Iran Center Colombia University.

Israuddin, Mohammad (1979). al-Biruni's contributions to Geography, in al-Biruni Commemorative Volume. Karachi: The Times Press.

Kamaruzaman, Kamar Oniah. (2003). Early Muslim Scholarship in Religionswissenschaft. Kuala Lumpur: ISTAC.

Muntashir, 'Abd al-Halim. (1968). Abū al-Rayhāān Al-Birūnī: Hayātuh, Mu'alafātuh, 'Abḥāthuh al'Ilmiyyah. Misr: Dar al-Ma'arif.

Nasim, K.B. (1979). Al-Biruni as an Astrologer, in al-Biruni Commemorative Volume. Karachi: The Times Press.

Nowshervi, Abdur Rauf. (1979). Al-Biruni Contribution to Natural Science, in al-Biruni Commemorative Volume. Karachi: The Times Press.

Othman, Mohd. Yusof Hj. (2009). Wacana Sejarah dan Falsafah Sians: Sains dan Masyarakat. Kuala Lumpur: Dewan Bahasa dan Pustaka. 
Reichenbach, Bruce R. (2001). Introduction to Critical Thinking. USA: Library of Congress.

Riaz, Ahmad. (n.d). "Al-Biruni: A Great Muslim Scientist, Philosopher, and Historian 973-1050 A.D.". Journal Pakistan Vision, 10 (1), 167-179.

Ruggiero, Vincent Ryan. (2002). Becoming a Critical Thinker. USA: Library of Congress.

Sachau, Edward C. (1910). Alberuni's India, vol. 1. London: Kegan Paul, Trench, Trubner \& Co. L.

Sachau, Edward C. (1910). Alberuni's India, vol. 2. London: Kegan Paul, Trench, Trubner \& Co. L.

Spuler, Bertold. (1979). The Political Situations of Iran at al-Biruni's lifetime, in al-Biruni Commemorative Volume. Karachi: The Times Press.

The UNESCO Courier. (June 1974). (27th Year), 2.40 French Francs.

Verlinden, Jay. (2005). Critical Thinking and Everyday Argument. Belmont, CA: Wadsworth.

Warris, Mohammad Mir. (1979). Al-Biruni's Research Methodology, in al-Biruni Commemorative Volume. Karachi: The Times Press. 